\title{
Inquiring English Teachers with Non-English Educational Backgrounds in Bali: Do They Know How to Teach English?
}

\author{
I.G.A. Lokita Purnamika Utami
}

\author{
${ }^{1}$ English Language Education, Universitas Pendidikan Ganesha, Singaraja, Bali \\ *Corresponding author. Email: lokitapurnamika@undiksha.ac.id
}

\begin{abstract}
The fact that Bali is an international tourism destination places the needs to teach English since an early age in Bali. However, research to date about English teachers of primary schools in Bali shows that not all of these teachers are holding English education qualification backgrounds. This qualitative study involved interviewing 4 non-English education qualification teachers who have to teach English regardless of their unsuitable qualification. This article presents a narrative of these teachers' experience of teaching English. It presents insight on what they understand about English teaching, the challenges they encountered, and the professional development disposition they had. The interview shows that these English teachers understand the principles of teaching English but for some reasons such as school support and English competency, they hardly put some of these principles into action. They are struggling with using the target language fully in the classroom, using interesting media, and providing more students-centered activities. These teachers have compliant disposition in attending formal professional development program and some selfdirected learning which is more oriented to their needs.
\end{abstract}

Keywords: non-English educational background, pedagogical knowledge, primary school English teacher, professional development

\section{INTRODUCTION}

Bali is a very famous tourism object which causes high demand for its people to be fluent in English communication. To support this needs, in Bali, English subject is provided in all education levels in Bali. The inclusion of English in primary schools is optional since the non-compulsory status of English subjects in primary school based on 2013 curriculum. In fact, in 2013 curriculum, English in primary school is placed as an extracurricular not a compulsory subject [1].

However, due to the high demand for English language competency at a young age, most primary schools in Bali offer English subjects [2]. The inclusion of English in primary schools in Bali raises concerns because there is no national standard for primary English instruction. Many English teachers in Bali's primary schools have no formal education in English [3]. Furthermore, because there is no definite English syllabus, these English teachers generally teach English using the worksheet book available at the bookstore. [3] discovered that a homeroom teacher who did not have a background in English education was required to teach English and she was frequently perplexed about what material to teach and what techniques to use for teaching
English. Furthermore, the syllabus and lesson plan that they used, were obtained from the internet and were not tailored to the needs of the students.

This phenomenon of non-English education teachers teaching English is intriguing because English teachers should ideally know how to teach English. [4] suggests that unqualified English teachers may be to blame for the poor quality of EFL instruction in Indonesia. Thus, primary school English teachers have strong pedagogical content knowledge, particularly in the area of teaching English to young learners. Teachers with strong pedagogical content knowledge understand how to teach a specific teaching material based on the characteristics of their students. [5]. It is well understood that there is a significant difference between teaching a foreign language to adults and teaching a foreign language to young learners. Teachers who teach English to young learners are expected to have a background in English education as well as experience working with young learners who have different learning characteristics than adults.

Pedagogical content knowledge is the combination of a teacher's knowledge of the learning material (or content) and the strategy for teaching that content to 
students. [6] explained that pedagogical content knowledge has several components, including subject matter knowledge, learner conception, and instructional strategies. Thus, the pedagogical content knowledge of primary English teachers covers the knowledge of the English learning material and the strategy of teaching the material for young learners.

Subject matter knowledge in the context of English learning consists of two components: language awareness and language proficiency. [7] defined language awareness as the teacher's understanding of the nature of the language, including grammar, pronunciation, vocabulary, and so on. Language proficiency is defined as the teacher's knowledge of language use, including the ability to speak and write in English. Furthermore, teaching English to children differs from teaching English to adults. As a result, teachers must be familiar with the learning characteristics of their students. In order to determine and design a good curriculum, the teacher must have a good pedagogical content knowledge. Thus, pedagogical content knowledge refers to the knowledge required to create a contextual syllabus for students and an engaging learning activity to facilitate students' learning based on their characteristics.

Several studies have been conducted in the past concerning the teaching of English to young learners. These studies focused on the use of learning media [8], the use of traditional games in teaching English to young learners [9], teaching English to young learners in a good learning environment (see [2, 10]), a learning model based on culture for primary school students in Bali [11], and the perceptions and implementation of teaching English to young learners (see [12], [3]).

Previous research has discovered the teachers' pedagogical aspect, perceptions, and implementation of teachers' pedagogical knowledge in teaching English to young learners. However, those studies did not focus on the case of teachers who did not have a background in English education. This article provides a description of how 4 non-English education qualification primary school teachers teach English in Bali. This description is based on preliminary observations of a case study focusing on the pedagogical content knowledge of English primary schools in Bali. In this study, pedagogical content knowledge of teaching English for young learners is divided into three categories: English subject matter knowledge (knowledge of language awareness and proficiency [7]), knowledge of young learners' characteristics (knowledge of the learners' characteristics, learning characteristics, learners' needs, motivation, and learning style [13]), and knowledge of instructional strategies (teacher's knowledge).

\section{METHOD}

The study was a qualitative study involving English teachers from primary schools in Bali. The study's participants were chosen on purpose. The following criteria were used to select participants: 1) The teachers have taught English in primary schools for more than ten years, 2) they have no English education qualifications, and 3) they teach English in various areas of Bali. These participants teach English in four locations on Bali: Buleleng, Klungkung, Karangasem, and Badung.

Table 1. Participants' Demographic information

\begin{tabular}{|l|l|l|l|l|}
\hline $\begin{array}{l}\text { Participants } \\
\text { code }\end{array}$ & Gender & $\begin{array}{l}\text { Length of } \\
\text { teaching } \\
\text { English }\end{array}$ & Areas & $\begin{array}{l}\text { Background of } \\
\text { education }\end{array}$ \\
\hline $\begin{array}{l}\text { T1/ Teacher } \\
1\end{array}$ & Female & 11 & Klungkung & $\begin{array}{l}\text { Primary school } \\
\text { teacher } \\
\text { education }\end{array}$ \\
\hline $\begin{array}{l}\text { T2/teacher } \\
2\end{array}$ & Female & 15 & Buleleng & $\begin{array}{l}\text { Bahasa Bali } \\
\text { education }\end{array}$ \\
\hline $\begin{array}{l}\text { T3/Teacher } \\
3\end{array}$ & Female & 18 & Karangasem & $\begin{array}{l}\text { Early Childhood } \\
\text { education }\end{array}$ \\
\hline $\begin{array}{l}\text { T4 Teacher } \\
4\end{array}$ & Male & 23 & Badung & $\begin{array}{l}\text { Hindu religion } \\
\text { education }\end{array}$ \\
\hline
\end{tabular}

The participants were interviewed individually using semi-structured interviews to help them understand the issue. Each person was interviewed three times, with each interview lasting 30-50 minutes on average. The interview questions cover three areas of pedagogical content knowledge in English teaching: language awareness and proficiency, characteristics of young learners, and instructional strategies. Besides interview, the data also obtained from observation which was done two times for each teacher. The researcher made notes during the observation. The interview and observation data were analyzed qualitatively using the steps of the interactive analysis model proposed by [14]. The steps in this model were as follows: data collection, data reduction, data display, and describing the verification conclusion. The data analysis was carried out in a continuous cycle until data saturation was reached.

\section{FINDINGS AND DISCUSSIONS}

\subsection{The knowledge of Subject Matter}

In this study, subject knowledge is defined as teacher knowledge about language awareness and language proficiency. Language awareness refers to a teacher's ability to use correct grammar, pronunciation, and vocabulary, whereas language proficiency refers to a teacher's knowledge of language use, including the ability to speak and write in English.

Because the study's participants are non-English education background teachers, they admitted to a lack of English proficiency. Teacher 1 frequently used Bahasa Indonesia in the classroom while teaching, despite admitting that "...English learners need more English exposure." Teacher 2 was of the opinion that "...using English fully in the classroom may discourage students from learning because the students hardly understand the lesson." However, it appears that they believe that some aspects of teaching should be done in English. "I always speak English when I greet or introduce important vocabulary," said Teacher 3. Meanwhile, Teacher 4 was of the opinion that "...closing the class and giving simple instructions should be in English." These teachers all agree that English should be used sparingly, with Bahasa 
Indonesia serving as the dominant language of instruction.

In general, all teachers agreed that primary school students do not yet have a large vocabulary. During the observation, it was discovered that they try to speak English as little as possible. Because they were not very proficient in speaking English, they reported that teaching English in part was also an effective practice. They placed a greater emphasis on how students correctly write or spell words. They also struggled with teaching pronunciation, claiming that they needed to "...be so reliant on online dictionaries to check word pronunciation." They only emphasized what was written in the textbook when it came to grammar. Aside from that, they admitted that they require additional assistance. They clearly understand the importance of teaching aspects of the English language. This is evident in their efforts to correct students' writing, spelling, and pronunciation; however, their knowledge of language awareness is insufficient to perform their duties effectively. They also believed that Bahasa Indonesia played an important role in English education, particularly in primary school. This finding is consistent with the findings of [15], who discovered that teachers can use their mother tongue to provide understandable input to students because students develop competence as a result of the teachers' extensive understandable input. Furthermore, they discovered that if the target language is difficult to understand, teachers can use their native language to assist students in understanding specific material.

\subsection{The knowledge of Young Learners' Characteristics}

Because of the differences in their characteristics, teaching children or young learners differs from teaching adults. Children, for example, like to learn from their experiences and construct the meaning of language based on real-life experiences like daily conversation. When children are learning, they also enjoy playing.

When asked about the characteristics of young learners, T1 and T2 stated that "...children like to play, and they are happier when they are engaged in some games." Teachers, according to T3, should be aware that "...young learners have very short attention spans, and we should always try something interesting, or we will 'lose' them." T4 also stated that "young learners learn better if they can see the object."

According to the interview, the participants have a good understanding of children's characteristics; however, how they apply this knowledge varies greatly. $\mathrm{T} 1, \mathrm{~T} 2$, and $\mathrm{T} 3 \mathrm{had}$ students practice their speaking skills by using some guided conversation from the text book. Despite its limitations, the conversations in the text book are quite contextual. During the observation, these three teachers frequently engaged students in conversation by engaging them in fun activities such as playing a game or singing a song. Their practices reflect their understanding that young students construct knowledge not only from teacher explanations but also from their surroundings. It is consistent with [16's] belief that learning is more effective. Young learners will gain a better understanding of the language if they can experience something on their own. The way these three teachers design their teaching activities demonstrates that they have good knowledge of the characteristics of young learners and apply this knowledge in their actual practice.

Not all teachers, however, exhibit the same parallelism between what they know and what they practice. For example, real-world objects can be used as teaching media. According to [17], young learners learn better in a real-world context because it allows them to capture things with their own senses and directly explore and experience them. T4 agreed with this concept during the interview, stating that children learn better if they can see or touch real-world objects. Nonetheless, T4 provided no real-object or media to increase students' learning motivation during two times of observation. This contradicts what he claimed to understand. In response to this discrepancy, he stated, "... I no longer use media because the one that we used to have is either broken or lost." He explained that the school once received some internship students who were in charge of developing the English media, and that he used them until they broke. He admitted that he had no knowledge of developing English teaching media, owing to his lack of computer skills. He hoped that "in the future, the schools will receive internship students again."

This finding demonstrates that education background and technological skills are indeed important factors in facilitating teaching performance. When we look at the education backgrounds of the participants, only T4 did not have a background related to young learners and language. T2 and T3 both have education in teaching young learners, and T3 has a background in language education. T4 has more experience teaching English, but he is less skilled in technology, which prevents him from performing technology-related instruction

\subsection{The knowledge of Subject Matter}

The participants admitted that they were drawn to the activities in the English text book that they were using. Because of this practice, classroom activities become predictable and monotonous. T1 stated that she rarely went beyond the book's contents because "I don't know what else to teach." I believe that as long as the student is happy while learning... As a routine, I have students sing some nursery songs." T1 and T3 relate this to the school's lack of facilities to facilitate the learning process. They stated that schools did not provide them with enough resources, such as books that provide supplementary material suitable for teaching English to young learners. T3 also stated that "we have insufficient teaching media at school, particularly for English teaching." Meanwhile, T4 stated, "It is difficult to design completely new learning activities, something I have never done." I guess I'm just trying to fill the English teaching void, and to be honest, it's only at the primary level."

The majority of teachers admitted that they teach English in a teacher-centered manner in which students 
listen to their explanation (mostly on grammar). They are more likely to teach students grammar concepts and provide some grammar practice. Their method of teaching grammar is known as the deductive approach. The term "deductive approach" refers to a teachercentered approach in which the teacher explains grammar points by explicitly explaining the details of grammatical pattern to students [18]. Some scholars [19], [20] view deductive approach to be ineffective for improving students' English proficiency because through deductive approach, the learners are typically passive agents with little opportunity to express and practice language.

It is clear from the interview that the participants believe that teaching English to young learners should be enjoyable and engaging. However, due to a lack of school support and the ability to do self-designed instruction, they are not always able to put their beliefs into action. Self-designed instruction is critical because children require various stimuli to activate their curiosity, which enhances learning. This stimulation could be provided by providing the opportunity to work with things and ideas. The teacher must provide them with learning activities that engage them in the learning process [21]. In relation to this characteristic, it is preferable for teachers to provide learning activities that allow students to directly learn things and ideas in the classroom. During the observation, however, the teachers appeared to dominate the class and tend to explain the material to the students without giving them a chance to express their thoughts on something.

\subsection{The challenges of teaching English}

From the interview, it was found that these nonEnglish education background teachers found some challenges in teaching English. These challenges were found in delivering the teaching material in English fluently, in designing interesting teaching media, and in using more students-centered activities.

These four teachers have made some attempts to cope with delivering teaching material in English. They managed to speak English on occasion and mostly facilitated learning in Bahasa Indonesia. When necessary, they translated the contents of the text book for the students. Some studies discuss the reasons for this practice. [22] explain this effort as a means of reducing their teaching anxiety. These four teachers reported that when their students spoke in Bahasa Indonesia in class, they seemed more at ease.[23] asserts that students are anxious about learning a foreign language if teachers only use the target foreign language as the medium of instruction.

It is debatable which language of instruction should be used in a foreign language class. Some experts believe that when learning a foreign language, learners should be exposed to the target language; however, other experts believe that the first language plays an important role in learning a second or foreign language. Nonetheless, it is critical that teachers feel comfortable communicating in the language she teaches. This means that their approach to selecting which language instruction to use is determined by the context or situation, rather than by their language proficiency.

Furthermore, teachers discovered that they were incompetent in creating engaging teaching media. Their method of teaching English is textbook-based. This practice also led them to adopt a teacher-centered approach to teaching. Students listened to their explanation before proceeding with the exercise. Because they followed the book's contents, these teachers reported that they do not design their teaching based on students' interests and needs. These practice of teaching based on a single text book should be avoided. [24] suggests that rather than controlling the class from the front, teachers should allow students to participate in decision making. This practice promotes learner autonomy where students not only learn from their own but also take responsibility of that learning. These teachers seems to struggle with the ability to design English teaching which allow students to take more control. Hence, they tend to replicate the text book contents into their teaching.

\subsection{The Professional development disposition}

These teachers admitted that they had made few efforts to improve their English teaching skills. T4 participated in a variety of professional development programs, including English teaching workshops. However, it was not done on a continuous basis, and she admitted that she did it because the principal assigned her to do so. "I am overwhelmed by the workshop demand and felt estranged because the other workshop participants were mostly qualified English teachers who appear to have better English proficiency than I do," she explained. [25] labels T1's practice as a compliant disposition to professional development policy because she prefers to obey the policy because she feels she has to. T4 also stated that the workshops were not relevant to her needs. She would have preferred that the workshops focus on training teachers on how to teach English with a practical focus or on improving English proficiency rather than solely on instructional theory. "The workshops had little impact on my practice," she admitted. Her report justifies what academics have said about the disadvantages of formal professional development. Formal Professional Development is frequently unrelated to the needs of teachers because it is based on school agendas (see [26], [27], and [28]) and has no impact on their actual practice [29]. This study findings on English teachers' inclination to do professional learning to do their job supports the study by [25].

T1, T2, and T3 did not attend any English teaching workshops, but they did try to understand words in the English textbook using an English-Indonesian dictionary and browse some English teaching ideas on the internet. Although it was not often, these teachers made an effort to improve their teaching performance. Some experts (see [30], [31], [32], [33]) have labeled the three teachers' professional development practice as professional learning rather than professional development because it 
is more informal, i.e., no expert telling them what to do and their practice is more self-directed.

From the interview these teachers seems to have compliant disposition when participating in formal professional development. For their own needs, however, these teachers turn to self-directed learning, which is less structured but more oriented to what they require. Despite the fact that they have no formal education in teaching English, they attempted self-directed learning to assist them in performing their job. They are aware of the importance of obtaining a degree in English education in order to provide effective English instruction. They might know the essential young learner characteristics, but they are having difficulty designing effective English instruction that requires more than just knowledge of student characteristics. Furthermore, pedagogical knowledge is a sophisticated type of knowledge that is difficult to obtain and not available to all who seek it.

\section{CONCLUSION}

Teaching English to young learners necessitates far more than pedagogical knowledge of young learners. English teachers at the primary level should be proficient in both English proficiency and the design and implementation of language strategies. The study's participants are aware of their limitations in developing effective English instruction for young learners. They encountered difficulties communicating in English in the classroom, creating teaching materials, and teaching through more student-centered activities. This study provides evidence that education background is an important part of the journey for teachers to become competent in the field in which they teach.

Although they have made efforts to participate in formal professional development such as one-time workshops or seminars, this has had little impact on their practice. Their obligation to do their job compels them to pursue professional development. These efforts are more needs-based or job-related. However, it is insufficient to prepare them to be effective English teachers at the primary level. Teachers should be encouraged to expand their knowledge and skills by participating in a variety of continuing professional development programs. As this is a small-scale exploratory study, a larger-scale study comparing English teachers' pedagogical content knowledge and practices is required.

\section{AUTHORS' CONTRIBUTIONS}

The author is the researcher in the study.

\section{ACKNOWLEDGMENTS}

This article is supported by Research and Community Service Institution of Universitas Pendidikan Ganesha.

\section{REFERENCES}

[1] N. Arif, "Removing English as compulsory subject from primary schools on the 2013 curriculum based on teachers ' opinion," International Journal of Scientific and Research Publications, vol. 5, no. 8, pp. 2-6, 2015.
[2] L. Artini, "Rich Language Learning Environment And Young Learners ' Literacy Skills In English,", Lingua Cultura, vol. 11, no. 1, pp. 19-24, 2017.

[3] N. P. Listyariani, L. P. Artini and N. N. Padmadewi, "Teachers ' Perceptions Of Teaching English For Young Learners And The Implementation In Public Primary Schools In Jembrana Sub-District,," Jurnal Pendidikan Bahasa Inggris Indonesia, vol. 6, no. 2, pp. 1-10, 2018.

[4] S. Soepriyatna, "Investigating and assessing competence of high school teachers of English in Indonesia," Malaysian Journal of ELT Research, vol. 8, no. 2, pp. 112,2016

[5] A. Habibi and M. Sofwan, "Teachers of English for Young Learners: An Analysis on Their English Proficiency and Profile," 2015. [Online]. Available: https://www.researchgate.net/publication/324184294_T eachers_of_English_for_Young_Learners_An_Analysis _on_Their_English_Proficiency_and_Profile.

[6] L. S. Shulman, "Those who understand: Knowledge growth in teaching," Educational Researcher, vol. 15, no. 2, pp. 4-14, 1986.

[7] S. Andrews, "The language awareness of the L2 teacher : its impact upon pedagogical practice," Language Awareness, vol. 10 (November 2001), no. 2, pp. 75-90, 2001.

[8] W. Aini, "Instructional Media in Teaching English to Young Learners: A Case Study in Elementary Schools in Kuningan.," Aini, W. 2013. Instructional Media in Teaching English to Young Learners: A Case Study in Elementary Schools in Kuningan. Retrieved from http://ejournal.upi.edu/index.php/L-E/article/view/350, 2013.

[9] Rusiana and Nuraeningsih, "Teaching English To Young Learners Through,", Rusiana, \& Nuraeningsih. (2016). Teaching English To Young Learners Through, 2(April), 193-200., vol. 2, no. April, p. 193-200., 2016.

[10] J. R. Putra, "Creating a Positive English Language Teaching and Learning Environment in EYL Classroom Setting.," in TEYLIN 2 from policy to practice, 2015.

[11] N. N. Padmadewi, P. K. Nitiasih and L. P. Artini, "Model Konseptual Pembelajaran Bahasa Inggris Berbasis Budaya Untuk Sekolah Dasar Di Bali," Jurnal Pendidikan dan Pengajaran, vol. 42, no. 3, pp. 170-177, 2009.

[12] N. W. W. Agustini, L. P. Artini and N. N. Padmadewi, "English Teachers ' Perceptions And Classroom Practices On Constructivism Values In Primary Schools In Badung Regency," PRASI, vol. 15, no. 2, pp. 1-11, 2019.

[13] F. Faisal, "Pedagogical Content Knowledge in English Language Teaching in Indonesia," in The 2nd Asia Pacific Education Conference 2014, Purwokerto, 2015.

[14] M. B. Miles and A. M. Hubermans, An Expanded Sourcebook: Qualitative Data Analysis, London: Sage Publication, 1994.

[15] S. A. Ostovar-Namaghi and S. Norouzi, "OstovarNamaghi, S. A.First Language Use in Teaching a Foreign Language: Theoretical Perspectives and Empirical Findings," US-China Foreign Language, vol. 13, no. 9, pp. 615-622, 2015.

[16] B. Musthafa, "Teaching English to Young Learners in Indonesia: Essential Requirements," Educationist, vol. 2, no. 120-125, p. 4, 2010. 
[17] F. Mustafa, M. Kirana and S. Bahri Ys, "Errors in EFL writing by junior high students in Indonesia.," International Journal of Research Studies in Language Learning,, vol. 6, no. 1, pp. 38-52, 2016.

[18] M. M. Obeidat and M. A. Alomari, "The Effect of Inductive and Deductive Teaching on EFL Undergraduates 'Achievement in Grammar at the Hashemite University in Jordan," International Journal of Higher Education, vol. 9, no. 2, pp. 208-288, 2020.

[19] K. Sik, " Tradition or Modernism in Grammar Teaching : Deductive vs . Inductive Approaches.," Procedia Social and Behavioral Sciences, vol. 197, no. 2, pp. 2141-2144, 2015.

[20] S. Negahdaripor and A. Amirghassemi, "The Effect of Deductive vs . Inductive Grammar Instruction on Iranian EFL Learners ' Spoken Accuracy and Fluency.," International Journal of Applied Linguistics and English Literature, vol. 5, no. 1, pp. 8-17, 2016.

[21] J. Juhana, " Teaching English to Young Learners: Some Points to be Considered.," Asian Journal of Education and E-Learning,, vol. 2, no. 1, pp. 43-46, 2014.

[22] N. Hasrina, Z. A. Aziz and S. S. Fitriani, "First language (L1) use in the EFL classroom: Perceptions of students and teachers.," English Education Journal, vol. 9, no. 3, pp. 406-421, 2018.

[23] P. M. Shah, N. H. Hashim, A. Yusof, R. Din, A. A. Karim and G. Rahman, "L2 learning challenges and needs of university students: A preliminary study," Procedia - Social and Behavioral Sciences, vol. 106, pp. 1669-1676, 2013.

[24] J. Harmer, The practice of English Language Teaching 4th edition, USA: PEARSON DUCATION, 2007.

[25] I. Utami and S. Prestridge, "How English Teachers Learn In Indonesia: Tension Between Policy-Driven And SelfDriven Professional Development," Teflin Journal, vol. 29, no. 2, pp. 245-265, 2018.

[26] Ashadi, "School teachers' voice in professional development.," in In Selected papers in English language teaching, Jakarta, RELO-IIEF, 2010, pp. 2032.

[27] D. Evans, S. Tate, R. Navarro and M. Nicolls, "Teacher education and professional development in Indonesia: A gap analysis.," USAID Gov, 2009.

[28] V. D. Opfer and D. Pedder, "The lost promise of teacher professional development in England," European Journal of Teacher Education, vol. 34, no. 1, pp. 3-24, 2011.

[29] J. Cho, "Teachers' perceptions of changes to teachingpractice and the influence of professional development: Experienced EFL teachers in South Korea," Victoria University of Wellington, Wellington, New Zealand). , 2014.

[30] J. Loughran, What expert teachers do: Enhancing professional knowledge for classroom practice., London: Routledge, 2010.

[31] P. Nilsson, "From concept to school practice: Professional learning for sustainable change in the primary science classroom," in Teacher learning that matters: International perspectives, M. Kooy \& K. van Veen (Eds.), Ed., Newyork, Routledge, 2012, pp. 235254.
[32] J. O'Brien and K. Jones, "O'BrProfessional learning or professional development? Or continuing professional learning and development? Changing terminology, policy and practice," Professional Development in Education, vol. 40, no. 5, pp. 683-687, 2014.

[33] M. Stevenson, J. G. O. K.-A. Hedberg and C. Howe, "Leading learning: The role of school leaders in supporting continuous professional development.," Professional Development in Education, vol. 42, no. 5, pp. 818-835, 2016. 